\title{
Panicle branching behaviour of rice Inpari IR Nutri Zinc
}

\author{
Tri Hastini ${ }^{1,{ }^{*}}$ Irma Noviana $^{2}$, Yati Haryati $^{2}$, Bebet Nurbaeti $^{2}$, M. Iskandar Ishaq ${ }^{1}$, Fyannita \\ Perdhana $^{2}$, Ratna Sari $^{2}$, and Iyan Septiana ${ }^{2}$ \\ ${ }^{1}$ Resources Research Group, West Java Assessment Institute for Agricultural Technology, Jl. \\ Kayuambon 80 Lembang Bandung Barat 40391, Indonesia \\ ${ }^{2}$ Cultivate Research Group, West Java Assessment Institute for Agricultural Technology, Jl. \\ Kayuambon 80 Lembang Bandung Barat 40391, Indonesia
}

\begin{abstract}
As a staple food, rice can be used as a bio fortification. For this necessity, Indonesian Agency for Agriculture Research and Development (IAARD) developed rice variety which was rich of $\mathrm{Zn}$ content to overcome child stunting. To understand the panicle branching behavior of Inpari IR Nutri Zinc, we collected panicle branching data from different sites and agronomical practices. Data were collected from three locations in West Java, i.e Cianjur, Majalengka, and Ciamis during May until October 2020. Among sites showed a significant differences of panicle branching. The best performance of Inpari IR Nutri Zinc panicle branching was showed at Majalengka rather than Ciamis and Cianjur. It was predicted because of temperature differences, as Cianjur's was higher than those Majalengka's and Ciamis'. Based on planting space, L5 was better than that L2 in number of grains per panicle, number of primary branches, number of secondary branches, total length of primary branches, and number of filledgrain per panicle characters. Meanwhile, L2 in Majalengka and Ciamis showed higher value in three panicle branching characters. Further, the L2 in Majalengka showed higher value and significantly difference than that in Ciamis in seven panicles branching characters bio pesticide application also affected some panicle branching characters significantly.
\end{abstract}

\section{Introduction}

As a staple food, rice was consumed by a major of civilization in the world. Beside as a source of energy, rice can be functioned as a source of micro-nutrients which are needed by the human being. The micro-nutrients contained in rice were iron $(\mathrm{Fe})$, Zinc $(\mathrm{Zn})$ and various vitamins and minerals, but rice does not supply these vitamins and minerals adequately [1]. On the other hand, it was reported that 2.7 billion people in the world were suffer from $\mathrm{Zn}$ deficiency [2]. There was also informed that the deficient of $\mathrm{Zn}$ and $\mathrm{Fe}$ in the world was more than two billion and become an important cause of 63 million loss of life annually [3]. The researchers and breeders gave the opinion of using staple food as a tool to overcome the zinc deficiency through bio fortification [4]. It was mentioned that

*Corresponding author: trihastini@gmail.com 
agronomic bio fortification is the most effective method and a promising way to increase zinc content in the rice grains [2].

The issue of child stunting is one of the cases of malnutrition. The prevalence of child stunting in Indonesia is approximately $37 \%$ at the national level [5]. Furthermore, there was the information that according to Indonesian National Survey the prevalence of stunting in children under 5 years was $37.2 \%$, while $19.6 \%$ was underweight, and $11.9 \%$ was combined overweight and obesity [6].

To overcome the case of stunting, Indonesian Agency for Agriculture Research and Development (IAARD) developed rice variety which was rich of $\mathrm{Zn}$ content in its grains. In 2019, it has been released Inpari IR Nutri Zinc as a rice variety with rich Zn content through the decree of the Indonesian minister of agriculture number 168/HK.540/C/01/2019. This variety was derived from the crossing of IR91153-AC 82/ IR05F102// IR 68144-2B-2-2-3-166 /// IRRI145. Based on the variety description, Inpari IR Nutri Zinc has the Zinc content of $29.54 \mathrm{ppm}$, and potential content is $34.51 \mathrm{ppm}$. The Inpari IR Nutri Zinc has the potential yield of $9.98 \mathrm{t} \mathrm{ha}^{-1}$, with the yield average is $6.21 \mathrm{tha}$ 1 . The grains size could be predicted as small, because the weight of 1,000 grains was only $24.60 \mathrm{~g}$.

Yield component and agronomical performance of Inpari IR Nutri Zinc such as plant height, plant shape, flag leaf, grain colour and potential yield had been informed in the description. As the panicle branching of rice play an important role in determining yield [7], it need to understand the panicle branching of Inpari IR Nutri Zinc. The research was aimed to find out the information of the performance of panicle branching in Inpari IR Nutri Zinc variety which planted at the different site and different agronomical practices. The result of the research can be suggested to be adopted in Inpari IR Nutri Zinc variety development.

\section{Materials and Methods}

Data were taken from three sites with various agronomical practices by the farmers in West Java, i.e Cianjur, Majalengka, and Ciamis during March until October 2020. Cianjur was located at pada $-6^{\circ} 48^{\prime} \mathrm{S}, 107^{\circ} 16^{\prime} \mathrm{E}\left(291 \mathrm{~m}\right.$ asl). While Majalengka was located at $-6^{\circ} 38^{\prime} \mathrm{S}$, $108^{\circ} 13^{\prime} \mathrm{E}$ (42 $\mathrm{m}$ asl), and Ciamis at $-7^{\circ} 37^{\prime} \mathrm{S}, 108^{\circ} 67^{\prime} \mathrm{E}$ (30.7 $\mathrm{m}$ asl).

Further, six environments and agronomical practices (A, B, C, D, E and F) considered as treatments and replicated three times (Table 1). The characters observed were measured on randomly five panicles from random hills as sample unit.

The characters observed were panicle length (PL), main axis length (MAL), number of node $(\mathrm{NN})$, number of grains per panicle (NGP), number of primary branches (NPB), number of secondary branches (NSB), primary branch length (PBL), secondary branch length (SBL), number of grains per primary branches (NGPB), number of grains per secondary branches (NGSB), total length of primary branches per panicle (TLPB), total length of secondary branches per panicle (TLSB), number of secondary branches per primary branch (SBperPB), total number of grains on secondary branches per panicle (TGSB), number of filled-grains per panicle (NFG), and number of unfilled-grains per panicle (NUFG). The technique of observation and measurement of characters observed were presents at Table 2 .

Descriptive statistic is analysed to ensure that the data is normally distributed and the variance is homogeneous. Kolmogorov-Smirnov test is used to analyse data distribution, while Bartlett'stest isused to analyse the variance homogeneity. Further, the data of experiment are analysed by one-way analysis of variance (ANOVA) of Randomized Block Design (RBD). Significant differences of mean are compared by using DMRT advanced 
analysis with $5 \%$ of alpha. Furthermore, to compare specific pairs of treatments, analysis of contrast is used.

Table 1. Environments and agronomical practices on Inpari IR Nutri Zinc variety which were studied its panicle branching

\begin{tabular}{|c|c|c|c|c|c|}
\hline \multirow[b]{2}{*}{ Treatments } & \multicolumn{5}{|c|}{ Description } \\
\hline & Site & $\begin{array}{l}\text { Planting } \\
\text { system }\end{array}$ & $\begin{array}{l}\text { Planting } \\
\text { space }\end{array}$ & $\begin{array}{l}\text { An-organic } \\
\text { fertilizer }\end{array}$ & Others \\
\hline A & Cianjur & $\begin{array}{l}\text { legowo } 5 \\
\text { (L5) }\end{array}$ & $\begin{array}{l}\text { Between legowo } 50 \\
\mathrm{~cm} \text {, in row } 25 \times 25 \mathrm{~cm}\end{array}$ & NPK $500 \mathrm{~kg} \cdot \mathrm{ha}^{-1}$ & - \\
\hline B & Cianjur & $\begin{array}{l}\text { legowo 2:1 } \\
\text { (L2) }\end{array}$ & $50 \times 25 \times 12.5 \mathrm{~cm}$ & NPK $500 \mathrm{~kg} \cdot \mathrm{ha}^{-1}$ & $\begin{array}{c}\text { Bio } \\
\text { pesticide }\end{array}$ \\
\hline C & Cianjur & $\begin{array}{l}\text { legowo 2:1 } \\
\text { (L2) }\end{array}$ & $50 \times 25 \times 12.5 \mathrm{~cm}$ & NPK $500 \mathrm{~kg} \cdot \mathrm{ha}^{-1}$ & - \\
\hline D & Majalengka & $\begin{array}{l}\text { legowo } 2: 1 \\
\text { (L2) }\end{array}$ & $40 \times 30 \times 15 \mathrm{~cm}$ & $\begin{array}{c}\text { NPK } 200 \mathrm{~kg} \cdot \mathrm{ha}^{-} \\
{ }^{1} \text { and Urea } 200 \\
\text { kg.ha }\end{array}$ & $\begin{array}{c}\text { Bio } \\
\text { pesticide }\end{array}$ \\
\hline E & Majalengka & $\begin{array}{l}\text { legowo 2:1 } \\
\text { (L2) }\end{array}$ & $40 \times 30 \times 15 \mathrm{~cm}$ & $\begin{array}{l}\text { NPK } 200 \mathrm{~kg} \cdot \mathrm{ha}^{-} \\
{ }^{1} \text { and Urea } 200 \\
\text { kg.ha }\end{array}$ & - \\
\hline $\mathrm{F}$ & Ciamis & $\begin{array}{l}\text { legowo 2:1 } \\
\text { (L2) }\end{array}$ & $40 \times 25 \times 25 \mathrm{~cm}$ & $\begin{array}{c}\text { NPK } 200 \mathrm{~kg} \cdot \mathrm{ha}^{-} \\
{ }^{1} \text { and Urea } 200 \\
\text { kg.ha }\end{array}$ & - \\
\hline
\end{tabular}

Table 2. The panicle branching characters observed of Inpari IR Nutri Zinc

\begin{tabular}{|c|c|}
\hline Characters & The measurement manner of panicle branches characters \\
\hline PL & measured from panicle neck to the tip of panicle \\
\hline MAL & measured from panicle neck to the tip of main axis \\
\hline NN & counted the number of nodes which a group of primary braches grow \\
\hline NGP & counted the total number of filled and unfilled grains per panicle \\
\hline NPB & counted the number of primary branches per panicle \\
\hline NSB & counted the number of secondary branches per panicle \\
\hline PBL & measured from the base to the tip of primary branch \\
\hline SBL & measured from the base to the tip of secondary branch \\
\hline NGPB & counted the number of grains per primary branch \\
\hline NGSB & counted the number of grains per secondary branch \\
\hline TLPB & total length of primary branches per panicle \\
\hline TLSB & total length of secondary branches per panicle \\
\hline SBperPB & counted the number of secondary branches per primary branch \\
\hline TGSB & counted the number of filled and unfilled grains on secondary branches per \\
panicle
\end{tabular}

Specific pairs of treatment that can be arranged to be compared are based on site, system and space of planting, and bio pesticide application (Table 3). Each pairs of treatment are arranged their contrast of coefficient (Table 4). 
Table 3. The treatment that can be compared by using contrast analysis

\begin{tabular}{|c|c|}
\hline Comparison & Description \\
\hline Site & Cianjur, Majalengka, Ciamis \\
\hline $\begin{array}{c}\text { System and space of } \\
\text { planting }\end{array}$ & $\begin{array}{c}\text { Legowo } 5(\mathrm{~L} 5), \text { Legowo } 2: 1(\mathrm{~L} 2) \text { with planting space } 50 \times 25 \times 12.2 \\
\mathrm{~cm}, 40 \times 30 \times 15 \mathrm{~cm}, \text { and } 40 \times 25 \times 25 \mathrm{~cm}\end{array}$ \\
\hline $\begin{array}{c}\text { Bio pesticide } \\
\text { application }\end{array}$ & Used bio pesticide or not \\
\hline
\end{tabular}

Table 4. Contrast coefficient that can be arranged from the treatments compared

\begin{tabular}{|c|c|c|c|c|c|c|c|}
\hline \multicolumn{8}{|c|}{ Based on site } \\
\hline Contras & A & $\mathrm{B}$ & $\mathrm{C}$ & $\mathrm{D}$ & $\mathrm{E}$ & $\mathrm{F}$ & Description \\
\hline & Cianjur & Cianjur & Cianjur & $\begin{array}{c}\text { Majaleng } \\
\text { ka }\end{array}$ & $\begin{array}{c}\text { Majaleng } \\
\text { ka }\end{array}$ & Ciamis & \\
\hline $\mathrm{C} 0$ & 1 & 1 & 1 & -1 & -1 & -1 & $\begin{array}{l}\text { (ABC) vs } \\
(\mathrm{DEF})\end{array}$ \\
\hline $\mathrm{C} 1$ & 0 & 0 & 0 & 1 & 1 & -2 & (DE) vs F \\
\hline \multicolumn{8}{|c|}{ Based on system and space of planting } \\
\hline & $\begin{array}{c}\text { L5 } \\
50 \times(25 \times 2 \\
5) \mathrm{cm}\end{array}$ & $\begin{array}{c}\mathrm{L} 2 \\
50 \times 25 \times 12 \\
.2 \mathrm{~cm}\end{array}$ & $\begin{array}{c}\mathrm{L} 2 \\
50 \times 25 \times 12 \\
.2 \mathrm{~cm}\end{array}$ & $\begin{array}{c}\mathrm{L} 2 \\
40 \times 30 \times 15 \\
\mathrm{~cm}\end{array}$ & $\begin{array}{c}\text { L2 } \\
40 \times 30 \times 15 \\
\mathrm{~cm}\end{array}$ & $\begin{array}{c}\mathrm{L} 2 \\
40 \times 25 \times 2 \\
5 \mathrm{~cm}\end{array}$ & \\
\hline $\mathrm{C} 0$ & 5 & -1 & -1 & -1 & -1 & -1 & $\begin{array}{c}\mathrm{A} \text { vs } \\
(\mathrm{ABCDEF})\end{array}$ \\
\hline $\mathrm{C} 1$ & 0 & 3 & 3 & -2 & -2 & -2 & $\begin{array}{c}(\mathrm{BC}) \mathrm{vs}(\mathrm{DE} \\
\mathrm{F})\end{array}$ \\
\hline $\mathrm{C} 2$ & 0 & 0 & 0 & 1 & 1 & -2 & $(\mathrm{DE}) \mathrm{vs} F$ \\
\hline \multicolumn{8}{|c|}{ Based on bio pesticide application } \\
\hline & $\begin{array}{l}\text { Non-bio } \\
\text { Cianjur }\end{array}$ & $\begin{array}{l}\text { Bio } \\
\text { Cianjur }\end{array}$ & $\begin{array}{l}\text { Non-bio } \\
\text { Cianjur }\end{array}$ & $\begin{array}{c}\text { Bio } \\
\text { Majaleng } \\
\text { ka }\end{array}$ & $\begin{array}{c}\text { Non-bio } \\
\text { Majaleng } \\
\text { ka }\end{array}$ & $\begin{array}{l}\text { Non-bio } \\
\text { Ciamis }\end{array}$ & \\
\hline $\mathrm{C} 0$ & 1 & -2 & 1 & -2 & 1 & 1 & $\begin{array}{c}\text { (ACEF) vs } \\
\text { (BD) }\end{array}$ \\
\hline $\mathrm{C} 1$ & 0 & 1 & 0 & -1 & 0 & 0 & B vs D \\
\hline
\end{tabular}

Bio $=$ bio pesticide application; Non-bio $=$ without bio pesticide application

All the data was statistical analyzed by using STAR nebula 2013 and Minitab 16.0 version.

\section{Result and Discussion}

Based on Shapiro-Wilk test, all the data showed a normal distribution. A normal distribution is one of the assumptions that must be met for analysis of variance. If the normality of data distribution is violated will result an unreliable or invalid interpretation and inference. The Shapiro-Wilk was chosen because it was the most powerful normality test tool [8]. The normality can be presented by using histogram of frequencies or a normal probability plot [9]. On the other hand, the homogeneity of variance was tested using Bartlett's test. The Bartlett's test was appropriate with normal distributions and it was independent from samples size [10]. The result of Bartlett's test showed homogeneity of variance in all characters observed except number of grains per panicle and number of unfilled grains per panicle ( $p$-value was 0.047 and 0.048 respectively).

Analysis of variance showed that there were effects of site and agronomical practices to panicle branching characters of PL, MAL, NGP, NPB, NSB, PBL, SBL, TLPB, TLSB, TGSB, and NFG of Inpari IR Nutri Zinc. Furthermore, advanced analysis by using DMRT test showed the differences of mean among the treatments (Table 5). The differences that 
occurred across sites and agronomical practices in panicle branching characters of Inpari IR Nutri Zinc were presumed caused by the genotype $\times$ environment, and also genotype $\times$ agronomical practices interaction.

Table 5. Means and differences of means of all panicle branching characters observed of Inpari IR Nutri Zinc

\begin{tabular}{|c|c|c|c|c|c|c|c|}
\hline Characters & $\mathrm{CV}$ & $\mathbf{A}$ & B & $\mathbf{C}$ & D & $\mathbf{E}$ & $\mathbf{F}$ \\
\hline PL & 4.26 & $\begin{array}{c}25.93 \\
\pm 1.25 \mathrm{a}\end{array}$ & $\begin{array}{c}24.48 \\
\pm 1.02 \mathrm{ab}\end{array}$ & $\begin{array}{c}22.73 \\
\pm 1.44 \mathrm{~b}\end{array}$ & $\begin{array}{c}26.29 \\
\pm 1.18 \mathrm{a}\end{array}$ & $\begin{array}{c}25.76 \\
\pm 0.24 \mathrm{a}\end{array}$ & $\begin{array}{c}25.63 \\
\pm 0.19 \mathrm{a}\end{array}$ \\
\hline MAL & 4.98 & $\begin{array}{c}16.12 \\
\pm 1.03 \mathrm{a}\end{array}$ & $\begin{array}{c}15.22 \\
\pm 0.87 \mathrm{a}\end{array}$ & $\begin{array}{c}13.15 \\
\pm 1.15 \mathrm{~b}\end{array}$ & $\begin{array}{c}16.75 \\
\pm 0.25 \mathrm{a}\end{array}$ & $\begin{array}{c}16.17 \\
\pm 0.54 \mathrm{a}\end{array}$ & $\begin{array}{c}15.45 \\
\pm 0.17 \mathrm{a}\end{array}$ \\
\hline $\mathrm{NN}$ & 6.95 & $\begin{array}{c}8.80 \\
\pm 0.35 \mathrm{a}\end{array}$ & $\begin{array}{c}8.67 \\
\pm 0.42 \mathrm{a}\end{array}$ & $\begin{array}{c}8.47 \\
\pm 0.61 \mathrm{a}\end{array}$ & $\begin{array}{c}9.67 \\
\pm 0.76 \mathrm{a}\end{array}$ & $\begin{array}{c}9.53 \\
\pm 0.83 \mathrm{a}\end{array}$ & $\begin{array}{c}8.67 \\
\pm 0.42 \mathrm{a}\end{array}$ \\
\hline NGP & 8.67 & $\begin{aligned} & 169.93 \\
\pm & 20.75 \mathrm{ab}\end{aligned}$ & $\begin{array}{r}146.53 \\
\pm 19.34 \mathrm{bc}\end{array}$ & $\begin{array}{c}111.60 \\
\pm 12.00 \mathrm{~d}\end{array}$ & $\begin{array}{l}179.53 \\
\pm 9.29 \mathrm{a}\end{array}$ & $\begin{array}{c}169.73 \\
\pm 1.60 \mathrm{ab}\end{array}$ & $\begin{array}{c}130.13 \\
\pm 2.55 \mathrm{~cd}\end{array}$ \\
\hline NPB & 3.55 & $\begin{array}{c}11.60 \\
\pm 0.20 \mathrm{~b}\end{array}$ & $\begin{array}{c}11.2 \\
\pm 0.00 \mathrm{~b}\end{array}$ & $\begin{array}{c}9.73 \\
\pm 0.42 \mathrm{c}\end{array}$ & $\begin{array}{c}12.40 \\
\pm 0.35 \mathrm{a}\end{array}$ & $\begin{array}{c}11.67 \\
\pm 0.31 \mathrm{~b}\end{array}$ & $\begin{array}{c}10.13 \\
\pm 0.64 \mathrm{c}\end{array}$ \\
\hline NSB & 12.30 & $\begin{array}{c}31.80 \\
\pm 5.79 \mathrm{ab}\end{array}$ & $\begin{array}{c}26.20 \\
\pm 4.78 \mathrm{bc}\end{array}$ & $\begin{array}{c}18.73 \\
\pm 2.10 \mathrm{~d}\end{array}$ & $\begin{array}{c}34.00 \\
\pm 2.03 \mathrm{a}\end{array}$ & $\begin{array}{c}32.40 \\
\pm 0.53 \mathrm{ab}\end{array}$ & $\begin{array}{c}23.07 \\
\pm 1.60 \mathrm{~cd}\end{array}$ \\
\hline PBL & 5.38 & $\begin{array}{c}11.08 \\
\pm 0.82 \mathrm{a}\end{array}$ & $\begin{array}{c}10.53 \\
\pm 0.62 \mathrm{a}\end{array}$ & $\begin{array}{c}9.44 \\
\pm 0.46 \mathrm{~b}\end{array}$ & $\begin{array}{c}11.31 \\
\pm 0.66 \mathrm{a}\end{array}$ & $\begin{array}{c}11.37 \\
\pm 0.13 \mathrm{a}\end{array}$ & $\begin{array}{c}10.85 \\
\pm 0.34 \mathrm{a}\end{array}$ \\
\hline SBL & 3.58 & $\begin{array}{c}2.75 \\
\pm 0.08 \mathrm{ab}\end{array}$ & $\begin{array}{c}2.70 \\
\pm 0.10 \mathrm{bc}\end{array}$ & $\begin{array}{c}2.55 \\
\pm 0.10 \mathrm{c}\end{array}$ & $\begin{array}{c}2.73 \\
\pm 0.13 \mathrm{ab}\end{array}$ & $\begin{array}{c}2.77 \\
\pm 0.03 \mathrm{ab}\end{array}$ & $\begin{array}{c}2.90 \\
\pm 0.07 \mathrm{a}\end{array}$ \\
\hline NGPB & 9.72 & $\begin{array}{c}14.45 \\
\pm 1.99 \mathrm{a}\end{array}$ & $\begin{array}{c}13.03 \\
\pm 1.71 \mathrm{a}\end{array}$ & $\begin{array}{c}11.41 \\
\pm 0.85 \mathrm{a}\end{array}$ & $\begin{array}{c}14.34 \\
\pm 0.92 \mathrm{a}\end{array}$ & $\begin{array}{c}14.54 \\
\pm 0.30 \mathrm{a}\end{array}$ & $\begin{array}{c}12.83 \\
\pm 1.09 \mathrm{a}\end{array}$ \\
\hline NGSB & 4.13 & $\begin{array}{c}3.22 \\
\pm 0.13 \mathrm{a}\end{array}$ & $\begin{array}{c}3.11 \\
\pm 0.16 \mathrm{a}\end{array}$ & $\begin{array}{c}2.96 \\
\pm 0.16 \mathrm{a}\end{array}$ & $\begin{array}{c}3.11 \\
\pm 0.11 \mathrm{a}\end{array}$ & $\begin{array}{c}3.15 \\
\pm 0.04 \mathrm{a}\end{array}$ & $\begin{array}{c}3.07 \\
\pm 0.11 \mathrm{a}\end{array}$ \\
\hline TLPB & 5.54 & $\begin{array}{c}129.21 \\
\pm 8.98 \mathrm{ab}\end{array}$ & $\begin{array}{c}118.08 \\
\pm 6.96 \mathrm{bc}\end{array}$ & $\begin{array}{l}92.10 \\
\pm 8.13 \mathrm{~d}\end{array}$ & $\begin{array}{l}140.43 \\
\pm 4.58 \mathrm{a}\end{array}$ & $\begin{array}{l}132.87 \\
\pm 3.65 \mathrm{a}\end{array}$ & $\begin{array}{l}110.20 \\
\pm 5.87 \mathrm{c}\end{array}$ \\
\hline TLSB & 15.69 & $\begin{array}{c}88.41 \\
\pm 19.02 \mathrm{a}\end{array}$ & $\begin{array}{c}71.46 \\
\pm 15.95 \mathrm{ab}\end{array}$ & $\begin{array}{c}48.27 \\
\pm 7.04 \mathrm{~b}\end{array}$ & $\begin{array}{c}93.35 \\
\pm 9.75 \mathrm{a}\end{array}$ & $\begin{array}{c}89.92 \\
\pm 2.12 \mathrm{a}\end{array}$ & $\begin{array}{c}67.23 \\
\pm 5.73 \mathrm{ab}\end{array}$ \\
\hline SBperPB & 12.96 & $\begin{array}{c}2.72 \\
\pm 0.49 \mathrm{ab}\end{array}$ & $\begin{array}{c}2.37 \\
\pm 0.39 \mathrm{ab}\end{array}$ & $\begin{array}{c}1.98 \\
\pm 0.16 \mathrm{c}\end{array}$ & $\begin{array}{c}2.77 \\
\pm 0.23 \mathrm{a}\end{array}$ & $\begin{array}{c}2.79 \\
\pm 0.09 \mathrm{ab}\end{array}$ & $\begin{aligned} & 2.29 \\
\pm & 0.31 \mathrm{bc}\end{aligned}$ \\
\hline TGSB & 16.03 & $\begin{array}{c}103.67 \\
\pm 22.81 \mathrm{a}\end{array}$ & $\begin{array}{c}82.53 \\
\pm 19.33 \mathrm{ab}\end{array}$ & $\begin{array}{c}56.47 \\
\pm 9.40 \mathrm{~b}\end{array}$ & $\begin{array}{c}107.20 \\
\pm 10.62 \mathrm{a}\end{array}$ & $\begin{array}{l}102.47 \\
\pm 1.60 \mathrm{a}\end{array}$ & $\begin{array}{c}71.53 \\
\pm 6.51 \mathrm{~b}\end{array}$ \\
\hline NFG & 8.57 & $\begin{array}{c}143.53 \\
\pm 14.49 \mathrm{a}\end{array}$ & $\begin{array}{c}118.33 \\
\pm 17.49 \mathrm{~b}\end{array}$ & $\begin{array}{c}94.07 \\
\pm 8.25 \mathrm{c}\end{array}$ & $\begin{array}{c}156.07 \\
\pm 12.60 \mathrm{a}\end{array}$ & $\begin{array}{l}151.53 \\
\pm 2.72 \mathrm{a}\end{array}$ & $\begin{array}{l}117.07 \\
\pm 2.61 \mathrm{~b}\end{array}$ \\
\hline NUFG & 37.03 & $26.53 \pm 7.11 \mathrm{a}$ & $\begin{array}{c}28.20 \\
\pm 11.07 \mathrm{a}\end{array}$ & $\begin{array}{c}17.53 \\
\pm 4.01 \mathrm{a}\end{array}$ & $\begin{array}{c}23.47 \\
\pm 14.34 \mathrm{a}\end{array}$ & $\begin{array}{c}18.20 \\
\pm 1.71 \mathrm{a}\end{array}$ & $\begin{array}{c}13.07 \\
\pm 1.36 \mathrm{a}\end{array}$ \\
\hline
\end{tabular}

Values in the same row which followed by the same letter was not different based on DMRT test on $5 \%$ of alpha; $\mathrm{CV}=$ coefficient of variation; $\mathrm{PL}=$ panicle length; $\mathrm{MAL}=$ main axis length; $\mathrm{NN}=$ node number; NGP $=$ number of grains per panicle; NPB = number of primary branches; NSB $=$ number of secondary branches; $\mathrm{PBL}=$ primary branch length; $\mathrm{SBL}=$ secondary branch length; $\mathrm{NGPB}=$ number of grains on primary branch; NGSB $=$ number of grains on secondary branch; TLPB $=$ total length of primary branches; TLSB $=$ total length of secondary branches; SBperPB $=$ number of secondary branches per primary branch; TGSB =; NFG = number of filled-grains; $\mathrm{NUFG}=$ number of unfilledgrains.

The A treatment resulted the longest panicle and main axis $(25.93 \mathrm{~cm}$ and $16.12 \mathrm{~cm}$ respectively), but it was not different with $\mathrm{B}, \mathrm{D}, \mathrm{E}$, and $\mathrm{F}$. The highest number of grains per panicle showed at D (179.53 grains), and not significant different A and E. Beside showed 
the highest number of grains per panicle, the $\mathrm{D}$ treatment also showed the highest number of primary and secondary panicle branches per panicle compared with others (12.40 and 34.00 respectively). Statistically, the A and E treatment showed the same number of primary and secondary panicle branches with $\mathrm{D}$. The length of primary branches across sites was the same except the $\mathrm{C}$ treatment was lower. Meanwhile, the length of secondary panicle branches, total length of primary panicle branches, total length of secondary panicle branches, number of secondary branches per primary branch, and total grains in secondary panicle branches showed more vary across sites. The lowest number of filled grains was showed in $\mathrm{C}$ treatment, while $\mathrm{B}$ and $\mathrm{F}$ was looked moderate. The highest one was in $\mathrm{A}, \mathrm{D}$, and $\mathrm{F}$. In the character of number of grains per primary branches, there were no differences among the treatments, as well as number of nodes, number of grains per secondary panicle branches, and number of un-filled grains per panicle.
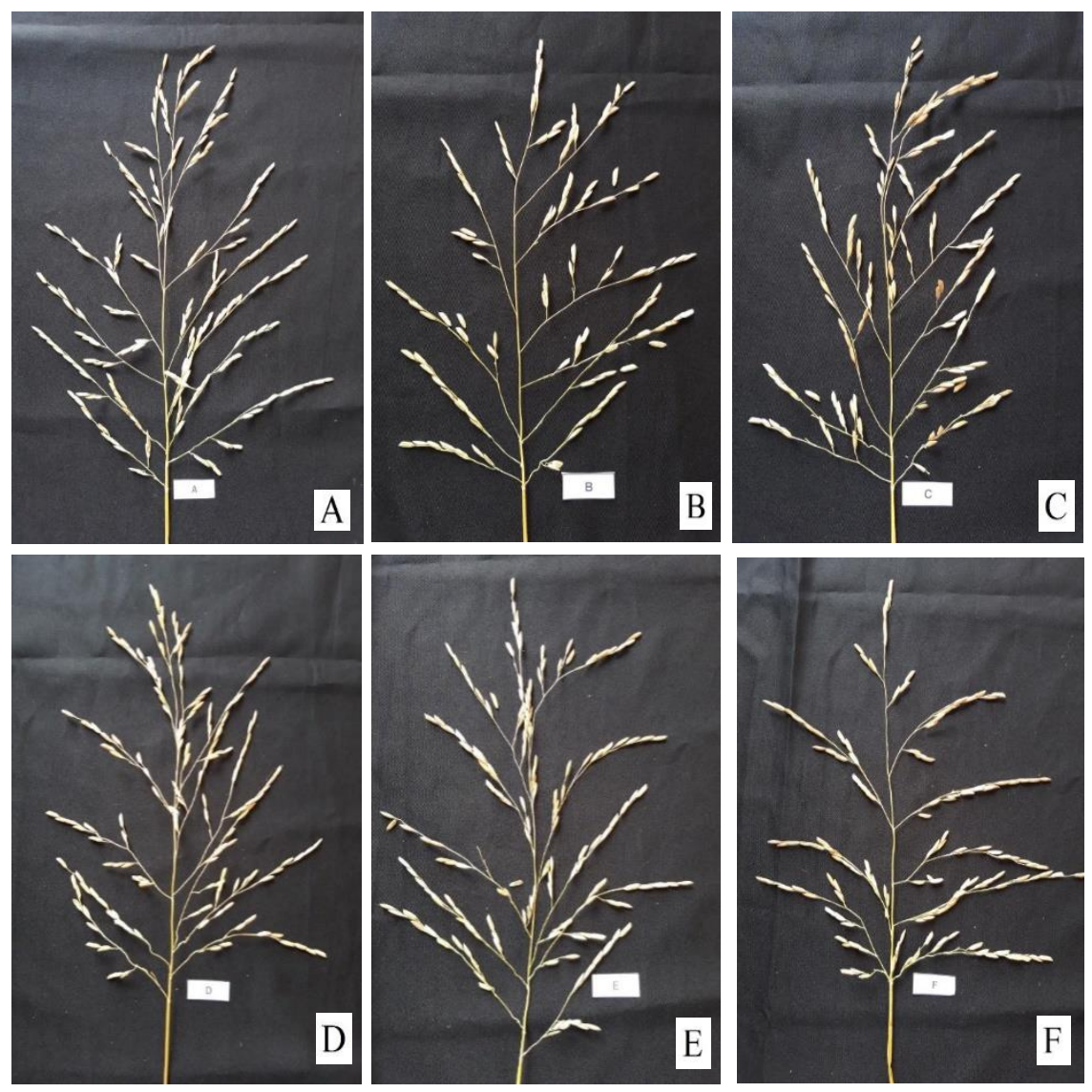

Fig 1. The performance of panicle branching of A, B, C, D, E, and F treatments

Contrast analysis based on site gave the information that there were differences among site on the characters observed. The result also showed the differences among system and planting space and the application of bio pesticide in a specific site.

The result showed that panicle length, main axis length, number of grain per panicle, number of primary branches, number of secondary branches, primary branch length, secondary branch length, total length of primary branches, total length of secondary branches, and number of filled-grains per panicle of Nutri Zinc were different between Cianjur and other sites (Majalengka and Ciamis). As presented at Table 5, Majalengka and 
Ciamis showed the higher value on those characters. While between Majalengka and Ciamis, the differences showed in the characters of number of grains per panicle, number of secondary branches, total length of primary branches, total length of secondary branches, total grains of secondary branches, and number of filled-grains per panicle. Majalengka showed better performance on those characters. It was reported that genotype $x$ environment interaction had significant correlation with primary branching [11].

Table 6. Comparation of characters based on site

\begin{tabular}{|c|c|c|c|c|}
\hline Characters & $\begin{array}{c}\text { MS C0 (contras (ABC) vs } \\
(\mathrm{DEF}))\end{array}$ & $\begin{array}{c}\text { Mean } \\
\text { (ABC) vs } \\
\text { (DEF) }\end{array}$ & $\begin{array}{c}\text { MS C1 (contras (DE) } \\
\text { vs F) }\end{array}$ & $\begin{array}{c}\text { Mean } \\
\text { (DE) vs F }\end{array}$ \\
\hline PL & $10.3361^{*}$ & $\begin{array}{c}24.38 \mathrm{vs} \\
25.89\end{array}$ & $0.3200^{\mathrm{ns}}$ & \\
\hline MAL & $7.5272^{* *}$ & $\begin{array}{c}14.83 \mathrm{vs} \\
16.12\end{array}$ & $2.0134^{\mathrm{ns}}$ & \\
\hline $\mathrm{NN}$ & $1.8689^{\mathrm{ns}}$ & & $1.7422^{\mathrm{ns}}$ & \\
\hline NGP & $1317.5556^{*}$ & $\begin{array}{c}142.69 \mathrm{vs} \\
159.80\end{array}$ & $3960.5000^{* *}$ & $\begin{array}{c}174.63 \mathrm{vs} \\
130.13\end{array}$ \\
\hline NPB & $1.3889^{*}$ & $\begin{array}{c}10.84 \text { vs } \\
11.40\end{array}$ & $7.2200^{* *}$ & $\begin{array}{c}12.03 \text { vs } \\
10.13\end{array}$ \\
\hline NSB & $81.0689^{*}$ & $\begin{array}{c}25.58 \mathrm{vs} \\
29.82\end{array}$ & $205.3689^{* *}$ & $\begin{array}{c}33.20 \mathrm{vs} \\
23.07\end{array}$ \\
\hline PBL & $3.0982^{*}$ & $\begin{array}{c}10.35 \mathrm{vs} \\
11.18\end{array}$ & $0.4749^{\mathrm{ns}}$ & \\
\hline SBL & $0.0788^{*}$ & 2.67 vs 2.80 & $0.0433^{\text {ns }}$ & \\
\hline NGPB & $4.0024^{\mathrm{ns}}$ & & $5.1527^{\mathrm{ns}}$ & \\
\hline NGSB & $0.0008^{\text {ns }}$ & & $0.0086^{\text {ns }}$ & \\
\hline TLPB & $973.1696^{* *}$ & $\begin{array}{c}113.13 \mathrm{vs} \\
127.83\end{array}$ & $1398.7818^{* *}$ & $\begin{array}{c}136.65 \mathrm{vs} \\
110.20 \\
\end{array}$ \\
\hline TLSB & $897.4672^{*}$ & $\begin{array}{c}69.38 \mathrm{vs} \\
83.50\end{array}$ & $1191.6962^{*}$ & $\begin{array}{c}91.64 \mathrm{vs} \\
67.23\end{array}$ \\
\hline SBperPB & $0.3007^{\mathrm{ns}}$ & & $0.4780^{\mathrm{ns}}$ & \\
\hline TGSB & $742.4089^{\text {ns }}$ & & $2217.7800^{* *}$ & $\begin{array}{c}104.83 \mathrm{vs} \\
71.53\end{array}$ \\
\hline NFG & $2362.1356^{* *}$ & $\begin{array}{c}118.64 \mathrm{vs} \\
141.56\end{array}$ & $2698.6756^{* *}$ & $\begin{array}{c}153.80 \mathrm{vs} \\
117.07\end{array}$ \\
\hline NUFG & $153.7089^{\mathrm{ns}}$ & & $120.6422^{\mathrm{ns}}$ & \\
\hline
\end{tabular}

$;^{* *}=$ significant at $5 \%$ and $1 \%$ of alpha respectively; ${ }^{\text {ns }}=$ not significant, MS $=$ Mean Square, $\mathrm{C}=$ contrast $\mathrm{PL}=$ panicle length; $\mathrm{MAL}=$ main axis length; $\mathrm{NN}=$ node number; $\mathrm{NGP}=$ number of grain per panicle; NPB = number of primary branches; NSB = number of secondary branches; $\mathrm{PBL}=$ primary branch length; $\mathrm{SBL}=$ secondary branch length; NGPB $=$ number of grain on primary branch; NGSB $=$ number of grain on secondary branch; TLPB $=$ total length of primary branches; TLSB $=$ total length of secondary branches; $\mathrm{SBperPB}=$ number of secondary branches per primary branch; TGSB =; NFG = number of filled-grains; $\mathrm{NUFG}=$ number of unfilled-grains.

Temperature was predicted as the cause of these differences. As shown at Fig 2, the highest temperature and the gap between highest and lowest temperature in Majalengka and Ciamis was not as large as one in Cianjur. Especially in March until October, when the experiment was conducted, the average of highest temperature in Majalengka and Ciamis was $30.141^{\circ} \mathrm{C}$, and in Cianjur was $32.707^{\circ} \mathrm{C}$. So as the gap of temperature in Majalengka and Ciamis were lower than those in Cianjur (Table 7). The temperature gap average in Majalengka and Ciamis was $5.16{ }^{\circ} \mathrm{C}$, and in Cianjur was $8.63{ }^{\circ} \mathrm{C}$. The stage on rice which the most sensitive to elevated temperature was flowering stage $[12,13]$. It was also reported 
that not only flowering stage, but also booting stage in rice was the most sensitive stage to elevated temperature [14]. The elevated temperature stress because yield decreased because of pollen viability degraded and finally decreased the grain yield.

Table 7. The highest and the lowest temperature and its gap in Majalengka, Ciamis and Cianjur during the experiment was conducted.

\begin{tabular}{|c|c|c|c|c|c|c|c|c|c|}
\hline \multirow{2}{*}{ Month } & \multicolumn{3}{|c|}{ Majalengka } & \multicolumn{3}{c|}{ Ciamis } & \multicolumn{3}{c|}{ Cianjur } \\
\cline { 2 - 11 } & HT & LT & HT-LT & HT & LT & HT-LT & HT & LT & HT-LT \\
\hline May & 31.452 & 25.839 & 5.613 & 31.452 & 25.839 & 5.613 & 32.806 & 24.867 & 7.940 \\
\hline June & 30.533 & 24.933 & 5.600 & 30.533 & 24.933 & 5.600 & 32.800 & 24.533 & 8.267 \\
\hline July & 29.742 & 24.935 & 4.806 & 29.742 & 24.935 & 4.806 & 32.645 & 23.968 & 8.677 \\
\hline August & 29.387 & 24.452 & 4.935 & 29.387 & 24.452 & 4.935 & 32.613 & 23.355 & 9.258 \\
\hline September & 29.767 & 24.900 & 4.867 & 29.767 & 24.867 & 4.900 & 32.733 & 23.733 & 9.000 \\
\hline October & 29.968 & 24.839 & 5.129 & 29.968 & 24.839 & 5.129 & 32.645 & 24.032 & 8.613 \\
\hline Average & 30.141 & 24.938 & 5.158 & 30.141 & 24.977 & 5.164 & 32.707 & 24.081 & 8.626 \\
\hline
\end{tabular}

Temperature data was adopted from AccuWeather 2020

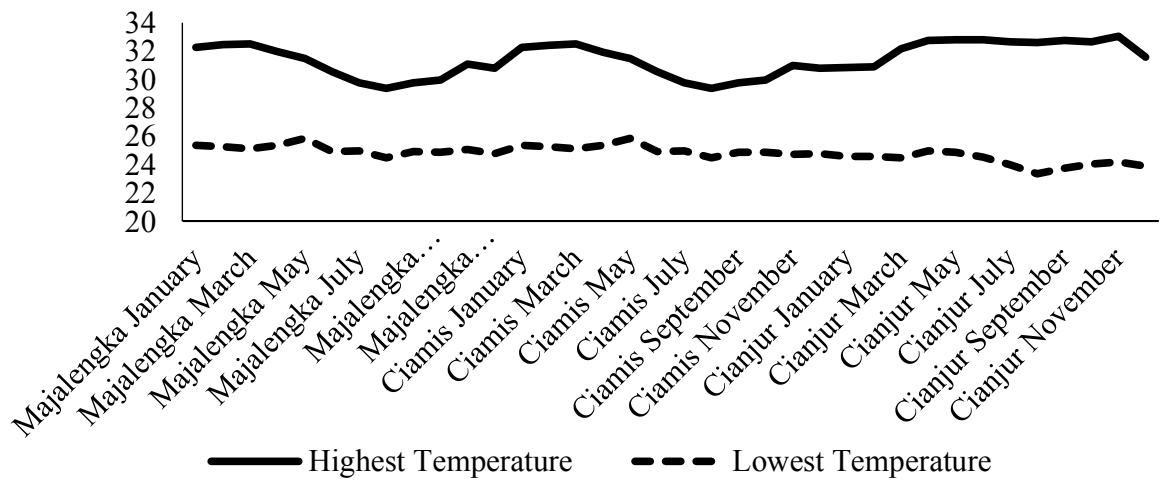

Fig. 2. The highest and lowest temperature average at three sites during 2020

Temperature had significant effect on number of panicle, panicle length, number of filled-grain, number of unfilled-grain, total number of grain, and rice yield [15]. The normal temperature of $32^{\circ} \mathrm{C}$ resulted better performance at the characters observed. Its mean that temperature in Majalengka and Ciamis were still included in optimum temperature while in Cianjur was above. It could be predicted that the low of number of filled-grain was caused by the elevated temperature. Heat stress during booting stage caused yield loss by reducing spikelet per panicle, seed-setting rate and 1,000 grains weight [16]. Not only the number of filled-grain was affected by the elevated temperature, but also the other panicle branching characters did. It could be elucidated that elevated temperature had a role as a trigger of heat stress. As the day temperature remains above from the optimum ones, the plant will respon as heat stress. The heat-responsive genes (HR) will react to the high ambient temperature. Under heat stress, the secondary metabolism-related genes significantly participate in synthesis of lignin, simple phenols, phenylpropanoid and flavonoids [17]. All the physiological processes will effect to the organ development. Heat stress at panicle initiation stage would destroy development of floral organs [13]. On the other hand, the increase of duration and level of elevated temperature significantly reduced dry matter and dry matter partitioning index of panicle [16]. It could be predicted that the decrease of dry matter and dry matter partitioning index affected to panicle branching formation.

Based on system and planting space, the significant different showed at number of grains per panicle, number of panicle branches, number of secondary branches, total length 
of primary branches, and number of filled-grains per panicle between L5 and L2. The L5 showed better value on those characters. The advanced structure of contrast, comparison between L2 with space of $50 \times 25 \times 12.5 \mathrm{~cm}$ vs L2 with space of $40 \times 30 \times 15 \mathrm{~cm}$ and $40 \times$ $25 \times 25 \mathrm{~cm}$, almost all the characters were significantly different except number of node, number of grains on secondary branches, and number of unfilled-grains per panicle. Better performance showed on the L2 with space of $40 \times 30 \times 15 \mathrm{~cm}$ and $40 \times 25 \times 25 \mathrm{~cm}$. While between L2 with space $40 \times 30 \times 15 \mathrm{~cm}$ and L2 with space $40 \times 25 \times 25 \mathrm{~cm}$, the differences showed at the characters of number of grains per panicle, number of panicle branches, number of secondary branches, total length of panicle branches, total length of secondary branches, total grains of secondary branches, and number of filled-grains per panicle (Table 8). The L2 with space of $40 \times 30 \times 15 \mathrm{~cm}$ better than L2 with space $40 \times 25$ $\times 25 \mathrm{~cm}$.

Table 8. Comparison of characters based on system and planting space

\begin{tabular}{|c|c|c|c|c|c|c|}
\hline Characters & $\begin{array}{l}\text { MS C0 (A vs } \\
\text { (BCDEF)) }\end{array}$ & $\begin{array}{c}\text { Mean A vs } \\
\text { (BCDEF) }\end{array}$ & $\begin{array}{c}\text { MS C1 ((BC) } \\
\text { vs (DEF)) }\end{array}$ & $\begin{array}{c}\text { Mean } \\
((\mathrm{BC}) \mathrm{vs} \\
(\mathrm{DEF})\end{array}$ & $\begin{array}{c}\text { MS C2 } \\
\text { ((DE) vs F) }\end{array}$ & $\begin{array}{c}\text { Mean } \\
((\mathrm{DE}) \\
\text { vs F } \\
\end{array}$ \\
\hline PL & $2.2531^{\mathrm{ns}}$ & & $18.8788^{* *}$ & $\begin{array}{c}23.60 \mathrm{vs} \\
25.89\end{array}$ & $0.3200^{\mathrm{ns}}$ & \\
\hline MAL & $1.4952^{\mathrm{ns}}$ & & $13.5334^{* *}$ & $\begin{array}{c}14.18 \mathrm{vs} \\
16.12\end{array}$ & $2.0134^{\mathrm{ns}}$ & \\
\hline $\mathrm{NN}$ & $0.1000^{\mathrm{ns}}$ & & $1.8778^{\mathrm{ns}}$ & & $1.7422^{\mathrm{ns}}$ & \\
\hline NGP & $1257.3884^{*}$ & $\begin{array}{c}169.93 \mathrm{vs} \\
147.51\end{array}$ & $3400.3360^{* *}$ & $\begin{array}{c}129.07 \\
\text { vs } \\
159.80\end{array}$ & $3960.5000^{* *}$ & $\begin{array}{c}174.63 \\
\text { vs } \\
130.13\end{array}$ \\
\hline NPB & $0.8218^{*}$ & $\begin{array}{c}11.60 \mathrm{vs} \\
11.03\end{array}$ & $3.1360^{* *}$ & $\begin{array}{c}10.47 \text { vs } \\
11.40\end{array}$ & $7.2200^{* *}$ & $\begin{array}{c}12.03 \mathrm{vs} \\
10.13\end{array}$ \\
\hline NSB & $60.5160^{*}$ & $\begin{array}{c}31.80 \mathrm{vs} \\
26.88\end{array}$ & $194.7751^{* *}$ & $\begin{array}{c}22.47 \text { vs } \\
29.82\end{array}$ & $205.3689^{* *}$ & $\begin{array}{c}33.20 \mathrm{vs} \\
23.07\end{array}$ \\
\hline PBL & $0.3610^{\mathrm{ns}}$ & & $5.1454^{* *}$ & $\begin{array}{c}9.98 \text { vs } \\
11.18\end{array}$ & $0.4749^{\mathrm{ns}}$ & \\
\hline SBL & $0.0017^{\mathrm{ns}}$ & & $0.1120^{* *}$ & $\begin{array}{c}2.62 \mathrm{vs} \\
2.80\end{array}$ & $0.0433^{\mathrm{ns}}$ & \\
\hline NGPB & $3.7095^{\mathrm{ns}}$ & & $10.2382^{*}$ & $\begin{array}{c}12.22 \mathrm{vs} \\
13.90\end{array}$ & $5.1527^{\mathrm{ns}}$ & \\
\hline NGSB & $0.0493^{\mathrm{ns}}$ & & $0.0205^{\mathrm{ns}}$ & & $0.0086^{\mathrm{ns}}$ & \\
\hline TLPB & $274.0453^{*}$ & $\begin{array}{c}129.21 \mathrm{vs} \\
118.74\end{array}$ & $1862.3515^{* *}$ & $\begin{array}{c}105.09 \\
\text { vs } \\
127.83\end{array}$ & $1398.7818^{* *}$ & $\begin{array}{c}136.65 \\
\text { vs } \\
110.20\end{array}$ \\
\hline TLSB & $515.6197^{\mathrm{ns}}$ & & $2011.2912^{* *}$ & $\begin{array}{c}59.86 \text { vs } \\
83.50\end{array}$ & $1191.8682^{*}$ & $\begin{array}{c}91.64 \mathrm{vs} \\
67.23\end{array}$ \\
\hline SBperPB & $0.1936^{\mathrm{ns}}$ & & $0.6941^{*}$ & $\begin{array}{c}2.18 \mathrm{vs} \\
2.61\end{array}$ & $0.4780^{\mathrm{ns}}$ & \\
\hline TGSB & $963.0151^{\mathrm{ns}}$ & & $2114.1160^{* *}$ & $\begin{array}{c}69.50 \mathrm{vs} \\
93.73\end{array}$ & $2217.7800^{* *}$ & $\begin{array}{c}104.83 \\
\text { vs } 71.53\end{array}$ \\
\hline NFG & $649.6360^{*}$ & $\begin{array}{c}143.53 \mathrm{vs} \\
127.41\end{array}$ & $4500.0551^{* *}$ & $\begin{array}{c}106.20 \\
\text { vs } \\
141.56\end{array}$ & $2698.6756^{* *}$ & $\begin{array}{c}153.80 \\
\text { vs } \\
117.07\end{array}$ \\
\hline NUFG & $103.6840^{\text {ns }}$ & & $76.9138^{\mathrm{ns}}$ & & $120.6422^{\mathrm{ns}}$ & \\
\hline
\end{tabular}


total length of secondary branches; SBperPB $=$ number of secondary branches per primary branch; TGSB $=; \mathrm{NFG}=$ number of filled-grains; $\mathrm{NUFG}=$ number of unfilled-grains.

Researchers had introduced the concept of genotype $\times$ environment interaction or GEI. This means that a genotype will show differ performance when it is planted across environment. Even the differences of the phenotype (traits and population) could be dramatically [18]. Many cases of GEI in rice had been reported. Wider spacing of $20 \mathrm{~cm} \times$ $20 \mathrm{~cm}$ of four modern rice cultivars shown superior performance in morpho-physiological and yield components compared with the closer spacing [19]. It indicated that different spacing of the same variety has given the contribution in different performance. Similar statement was informed previously that the rice plot with larger spacing $(30 \mathrm{~cm} \times 30 \mathrm{~cm})$ shown a larger diameter in stem and root, and leaf surface area was more productive [20].

Spacing had significant effect on effective tillers hill ${ }^{-1}$ [21]. Wider spacing resulted more number of effective tillers hill ${ }^{-1}$. Panicle length also affected by the spacing. It seems that spacing also affected the panicle branching characters. The characters of panicle length, main axis length, number of grains per panicle, number of primary branches per panicle, number of secondary branches per panicle, primary branches length, secondary branches length, total length of primary branches, total length of secondary branches, number of secondary branches per panicle branch, total grains of secondary branches, and number of filled-grains were lower in narrower spacing than those in wider ones. The treatment with narrower spacing $(\mathrm{B}, \mathrm{C}$, and $\mathrm{F})$ showed lower value in the characters above. More tiller number per hill ${ }^{-1}$ was caused by more available nutrient and light interception for the plant [21]. Dry matter accumulation of rice was higher in the wider spacing [22]. Light was very important for plant growth by providing the energy for photosynthesis processes [23]. The increase of light intensity had revealed improved leaf thickness of rice, although at different genotype.

Table 9. Comparison of characters based on application of bio pesticide in a specific site

\begin{tabular}{|c|c|c|c|c|}
\hline Characters & $\begin{array}{c}\text { MS C0 ((ACEF) vs } \\
\text { (BD)) }\end{array}$ & $\begin{array}{c}\text { Mean ((ACEF) vs } \\
\text { (BD) }\end{array}$ & $\begin{array}{l}\text { MS C1 (B vs } \\
\text { D) }\end{array}$ & Mean (B vs D) \\
\hline PL & $0.5675^{\text {ns }}$ & & $4.9323^{\text {ns }}$ & \\
\hline MAL & $2.3205^{\mathrm{ns}}$ & & $3.4961^{*}$ & 15.22 vs 16.75 \\
\hline $\mathrm{NN}$ & $0.3600^{\text {ns }}$ & & $1.5000^{\mathrm{ns}}$ & \\
\hline NGP & $1250.8011^{*}$ & 150.42 vs 163.03 & $1633.5000^{*}$ & $\begin{array}{c}146.53 \text { vs } \\
179.53\end{array}$ \\
\hline NPB & $4.1344^{* *}$ & 11.00 vs 11.80 & $2.1600^{* *}$ & 11.20 vs 12.40 \\
\hline NSB & $51.8400^{\mathrm{ns}}$ & & $91.2600^{*}$ & 26.20 vs 34.00 \\
\hline PBL & $0.2118^{\text {ns }}$ & & $0.9191^{\mathrm{ns}}$ & \\
\hline SBL & $0.0025^{\mathrm{ns}}$ & & $0.0019^{\text {ns }}$ & \\
\hline NGPB & $0.5817^{\mathrm{ns}}$ & & $2.5863^{\mathrm{ns}}$ & \\
\hline NGSB & $0.0007^{\mathrm{ns}}$ & & $0.0001^{\mathrm{ns}}$ & \\
\hline TLPB & $692.4617^{* *}$ & 118.06 vs 129.25 & $749.0603^{* *}$ & $\begin{array}{c}118.08 \text { vs } \\
140.43\end{array}$ \\
\hline TLSB & $320.5293^{\text {ns }}$ & & $718.9771^{*}$ & 71.46 vs 93.35 \\
\hline SBperPB & $0.0641^{\mathrm{ns}}$ & & $0.2300^{\mathrm{ns}}$ & \\
\hline TGSB & $513.7778^{\text {ns }}$ & & $912.6667^{\text {ns }}$ & \\
\hline NFG & $453.6900^{\mathrm{ns}}$ & & $2135.7067^{* *}$ & $\begin{array}{c}118.33 \mathrm{vs} \\
156.07\end{array}$ \\
\hline NUFG & $196.0000^{\mathrm{ns}}$ & & $33.6067^{\mathrm{ns}}$ & \\
\hline
\end{tabular}

$;^{* *}=$ significant at $5 \%$ and $1 \%$ of alpha respectively; ${ }^{\text {ns }}=$ not significant, MS $=$ Mean Square, $\mathrm{C}=$ contrast; $\mathrm{PL}=$ panicle length; $\mathrm{MAL}=$ main axis length; $\mathrm{NN}=$ node number; $\mathrm{NGP}=$ number of grain per panicle; NPB $=$ number of primary branches; NSB $=$ number of secondary branches; $\mathrm{PBL}=$ 
primary branch length; $\mathrm{SBL}=$ secondary branch length; $\mathrm{NGPB}=$ number of grain on primary branch; $\mathrm{NGSB}=$ number of grain on secondary branch; TLPB $=$ total length of primary branches; TLSB $=$ total length of secondary branches; SBperPB $=$ number of secondary branches per primary branch; $\mathrm{TGSB}=; \mathrm{NFG}=$ number of filled-grains; $\mathrm{NUFG}=$ number of unfilled-grains.

Bio pesticide application showed the significant effect on the characters of number of grains per panicle, number of primary branches, and total length of primary branches (Table 9). The three characters showed higher value in the treatment of bio pesticide application. The average value for the character of number of grains per panicle, number of primary branches, and total length of primary branches, without vs with bio pesticide application was 145.35 vs $163.03,10.78$ vs 11.80 , and 116.10 vs 129.31 respectively. At the previous study, it was revealed that bio pesticide application had significant and positive effect on plant height, productive spikelet per plant percentage, and yield related-traits such as productive spikelet, weight of 100 grains and grain yield per plant [24]. On the other report, it was also declared that bio pesticide had positive and significant effect on number per panicle per $\mathrm{m}^{2}$, panicle length, spikelet per productive panicle percentage, 1000 grains weight, and grain yield per $\mathrm{m}^{2}$ [25]. The comparison between bio pesticide application in Cianjur vs Majalengka showed the significant different in the characters of main axis length, number of grains per panicle, number of primary branches, number of secondary branches, total length of primary branches, total length of secondary branches, and number of filled-grains per panicle. Bio pesticide application showed significant effect on all seven characters.

\section{Conclusion}

Panicle branching behaviour of Inpari IR Nutri Zinc was varying among sites and agronomical practices. Majalengka showed the best performance, followed by Ciamis and Cianjur. The higher temperature was predicted as the cause of the inferiority of panicle performance in Cianjur. Based on planting space, the L5 was showed the best performance in number of grains per panicle, number of primary branches, number of secondary branches, total length of panicle branches, and number of filled-grains per panicle. The L2 in Majalengka and Ciamis was better and significantly different than those in Cianjur in the character of node number, number of grains on secondary branches, and number of unfilled-grain per panicle. The character of number of grains per panicle, number of primary branches, number of secondary branches, total length of primary branches, total length of secondary branches, total grains on secondary branches, and number of filledgrains per panicle in Majalengka showed higher value and significantly different than those in Ciamis. Bio pesticide had the effect on the characters of number of grains per panicle, number of primary branches, total length of primary branches, main axis length, number of secondary branches, total length of secondary branches, and number of filled-grains per panicle.

\section{References}

1. M. N. M. Fairulnizal, M.K. Norhayati, A. Zaiton, A.H. Norliza, S. Rusidah, A.R. Aswir, M. Suraiami, M.N. M. Naeem, A. Jo-Lyn, J.M. Azerulazree, B. Vimala, T.M. Zainuldin, Int. Food. Res. J.22, 768 (2015)

2. M.K. Singh, S.J. Prasad, Sect. B Biol. Sci. 84, 1 (2014)

3. S.S. Myers, A. Zanobetti, I. Kloog, P. Huybers, A.D.B. Leakey,. A.J. Bloom, E. Carlisle, L.H. Dietterich, G. Fitzgerald, T. Hasegawa, N.M. Holbrook, R.I. Nelson, 
M.J. Ottman, V. Raboy, H. Sakai, K.A. Sartor, K.A. J. Scwarrtz, S. Seneweera, M. Tausz, Y. Usui, Nature. 510, 139 (2014)

4. Q. Zaman, Z. Aslam, M. Yaseen, M.Z Ihsan, A Khaliq, S Fahad, P.M.A Ramzani, M Naeem, Arch. Agron. Soil Sci. 64 (2017)

5. T. Beal, A. Tumilowicz, A. Sutrisna, D. Izwardy, Matern Child Nutr. 14, 1 (2018)

6. C.N. Rachmi, K.E. Agho, M. Li, L.A. Baur, Plos ONE. 11, 1 (2016)

7. X. Bai, Y. Huang, D. Mao, M. Wen, L. Zhang, Y. Xing, Sci Rep. 6, 1(2016)

8. N.M. Razali, Y.B. Wah, Journal of Statistical Modeling and Analysis. 2, 21 (2011)

9. G.D. Garson.Testing Statistical Assumptions (North Carolina State University. School of Public and International Affairs, 2012)

10. Y. Wang, P.R. Gil, Y.H. Chen, J.D. Kromrey, E.S. Kim, T. Pham, D. Nguyen, J.L. Romano, Educ. Psychol. Meas. 77, 1 (2016)

11. L. Nassir, Int. J. Plant. Breed. Genet. 7, 105 (2013)

12. Z. Yang, Z. Zhang, T. Zhang, S. Fahad, K. Cui, L. Nie, S. Peng, J. Huang, Front. Plant. Sci. 8, 1908 (2017)

13. W. Yaliang, W. Lei, Z. Jianxia, H. Shengbo, C. Huizhe, X. Jing, Z. Yikai, Z. Yongjun, S. Qinghua, Z. Defeng, Z. Yuping, Rice Sci. 26, 1 (2019)

14. F. Shah, J. Huang, K. Cui, L. Nie, T. Shah, C. Chen, K. Wang, J. Agric. Sci. 149, 545 (2011)

15. R. Ghadirnezhad, A. Fallah, Int. J. Agron. 2014, 1 (2014)

16. F. Zhen, J. Zhou, A. Mahmood, W. Wang, X. Chang, B. Liu, L. Liu, W. Cao, Y. Zhu, L. Tang, The Crop Journal, 8, 194 (2020)

17. X. Zang, J. Li, A. Liu, J. Zou, X. Zhou, J. Xiang, W. Rerksiri, Y. Peng, X. Xiong, X. Chen, PloSONE. 7, e49652 (2012)

18. J.B. Saltz, A.M. Bell, J. Flint, R. Gomulkiewicz, K.A. Hughes, J. Keagy, Ecol. Evol. 8, 6342 (2018)

19. M.M.A. Mondal, A.B. Puteh, M.R. Ismail, M.Y. Rafii, Int. J. Agric. Biol. 15, 175 (2013)

20. T. Chapagain, E. Yamaji, Paddy Water Environ. 8, 81(2010)

21. M.S. Alam, M.A. Baki, M.S. Sultana, K.J. Ali, M.S. Islam, Int. J. Agr. \& Agri. R.2, 10(2012)

22. G. Priyanka, G.D. Sharma, R. Rachana, B. Lal, Int. J. Res. BioSciences. 2, 53 (2013)

23. J. Gu, Z. Zhou, Z. Li, Y. Chen, Z. Wang, H. Zhang, J. Yang, Front. Plant. Sci. 8, 1082 (2017)

24. P.S.D. Kamarulzaman, S. Yusup, N. Osman, N.H.R. Yusof, B.W.B. Kueh, R. Talib, Sustain ChemParm. 7, 36 (2018)

25. P.S.D. Kamarulzaman, D.J. Dailin, S. Yusup, N.B. Osman, L.F. Chuah, A. Bokhari, American Journal of Biochemistry. 6, 137 (2016) 